UDK 528.94

\title{
DEVELOPMENT OF THE MAIN DIRECTIONS ON PROTECTION MOUNTAIN AND MEADOW PEATY SOILS OF BASINS OF THE RIVERS OF THE NORTHEAST SLOPE OF GREATER CAUCASUS (ON THE EXAMPLE OF THE RIVER GUDIALCHAY)
}

\author{
Ilham Ildirim oglu MARDANOV \\ Sumgait State University, 43rd quarter, Sumgait, Az 5008, Azerbaijan Republic \\ E-mail: geography.sumqayit@mail.ru
}

Received 19 May 2014; accepted 30 November 2016

\begin{abstract}
Mountain territories of the Azerbaijani part of Greater Caucasus differ increasing impact of different types of human activity on mountain meadow landscape complexes with their unpredictable consequences to which research works of many scientists are devoted. For this reason there is a need of implementation of the complex analysis of conditions of formation of mountain meadow peaty soils, their physical and chemical indicators and structure, opportunities of implementation of urgent nature protection actions.

Keywords: anthropogenous, relief, landscapes, Range, highlands, assessment, territory, development, alpine, massif.
\end{abstract}

\section{Introduction}

The territory of a river basin of Gudialchay which is flowing down from the Northeast slope of Greater Caucasus everything is more actively involved in a field of activity of travel business against the proceeding pasturable animal husbandry which is based on subalpine and Alpine meadows that is even more often mentioned as an anthropogenous factor of a relief forming (Kyul', Marchenko 2012; Alizade, Tarikhazer 2010). In this regard there is a need of the account and an assessment of all factors of the environment, capable to affect life of the population and tourists as now, and in the future. Elements of mountain landscapes of highlands of Greater Caucasus within the Azerbaijan Republic the soil cover under the influence of which there was a difficult system of managing as shows the saved up experience of scientific researches needing improvement taking into account ecological need and economic feasibility is important.

\section{Object and methods of researches}

Highlands of the Northeast slope of Greater Caucasus differs a wide strip of a mountain meadow natural zone, throughout centuries used as summer pastures and haymakings. Smaller biases of surfaces of slopes in comparison with the Southern macro slope of Greater
Caucasus Range cause formation of more powerful cover mountain meadow, including, mountain meadow peaty soils. This type of soils occupies the big spaces in mountain part of the Northeast slope of Greater Caucasus Range and on Lateral Range within Azerbaijan which are cut the valley by the river Gudialchay flowing into the Caspian Sea and forming in this area the deep gorge. This site also as well as the Southern slope of Greater Caucasus Range quite often became the arena of formation and a descent of mud streams, concentrating power of the elements which is natural manifestation of adverse geodynamic processes - a soil erosion, a denudation and landslides.

At present the extensive literary material, allowing to characterize territories of formation of mountain meadow peaty soils of a river basin of Gudialchay accumulated, to give an assessment of their spatial differentiations depending on distinctions of an environment, character and degree of intensity of anthropogenous impact on natural landscapes. Today it is known that this site of Lateral Range is characterized by intensive development of landslide processes, in strong degree changing shape of mountain meadows and hay makings, making changes to structure of land grounds and creating various social problems for the population of many villages of the region. The territory round the settlement Kalaykhudat where landslide processes 
substantially changed not only a micro relief in this regard is indicative, but also in strong degree broke integrity of a soil cover, having made this site the probable torrential center for the pool Gudialchay, posing potential hazard to life of the population of the village. The analysis of the scientific literature devoted to studying of climatic, geo morphological and soil conditions in upper courses of Gudialchay, together with interpretation of aerial photographs of scale 1:25000 gives the chance to reveal major factors of development soil and ecological and as a whole, a landscape situation. Studying of such pictures confirms existence of a wide valley of this river in adjacent to a watershed of Greater Caucasus Range of the the poorly inclined territory revealed as a result of cameral works on a topographic map and route forwarding researches. In this territory old agricultural grounds on the terraced slopes are clearly traced that eloquently testifies to evolution of economic system of the region for the last century. These sites of distribution of mountain meadow peaty soils can be used in the near future for placement of tourist objects, on condition of observance of necessary nature protection measures.

Forwarding works meant a capture of soil samples for their subsequent cameral processing, along with visual researches that formed the basis for an objective assessment of a soil and landscape situation in the difficult area in the relief relation.

\section{Results of researches}

Researches show that in the Azerbaijani part of Greater Caucasus, the most powerful typical mountain meadow peaty soils are widespread on northern slopes and spurs of the Main and Lateral ridges.

For typical powerful mountain meadow peaty soils the coal mine 1411 put by G. A. Aliev (1978) on a northern slope of Shakhdag is characteristic. The land relief is the poorly inclined, bias change on $100 \mathrm{~m}$ makes $1 \mathrm{~m}$. Exposition northwest, vegetation mesophilic-meadow. From fodder plants meet a mountain clover (Trifolium repens, T. triencephalum), and from the mezofil of Nymphaea L. Alchymella and many others. The major breeds limestones top Yura. Thus rather flat relief with the minimum bias of the district, apparently, is the main reason of formation of more powerful soil profile, not characteristic for the most part of highlands of the Azerbaijani part of Greater Caucasus. However and such sites can be characterized by existence strongly and moderately eroded sites, with the rarefied vegetation and the worsened specific structure. Especially it should be noted vegetation of settlements which though differ dense vegetation, but the majority of plants on these sites treat the weeds which don't have valuable nutritious properties, and at times - poisonous. Cespitose and peaty mountain meadow soils with a average powerful profile (coal mine 1406) were described by G. A. Aliev (1978) in $4 \mathrm{~km}$ to the north of Shakhdag, at the height of $2700 \mathrm{~m}$ above sea level. Soils were formed on Yura's limestones under the Alpine meadows.

Lack of the horizon is thus observed In that can be explained with severe climatic and relief conditions for the soil formation, bringing to weak differentiation of a soil profile.

The analysis of the description of the section No. 21 put on the southern slope of Lateral Range in a valley of Gudialchay shows that the profile is truncated, considerable insolation (as east exposition) promotes intensive decomposition of organic part and formation of powdery structure.

The section No. 22 put by us in the 2008th year on an artificial ancient terrace in kilometer to the East from the settlement Hynalyg, at the absolute height of 1950 meters has similar lines of a profile also.

Soil mountain meadow peaty subalpine, slightly eroded, skeletal. Bias of a surface of a site $27-30^{\circ}$. Projective covering of $90-100 \%$. The top $0-5 \mathrm{sm}$ the horizon of $A_{1}$ is characterized granular powdery sod dark-brown coloring with rare stones that can speak about incompleteness of soil forming process. The underlying horizon of $\mathrm{A}_{2}$ located at a depth of 5-13 sm, has brown coloring, granular powdery structure, with numerous small and large fragments of breeds. The horizon B 13-23 sm also has dark-brown color, places with a greenish shade and coarse-grained structure. Below the soil profile sharply passes to maternal breed.

The analysis of quantity of nutritious elements in this section showed that the sum of the absorbed ammonium $\left(\mathrm{N} / \mathrm{NH}_{3}\right)$ in the top layer made $35.47 \mathrm{mg} / \mathrm{kg}$, sharply decreasing from top to bottom to 18.43 in the second and to 10.35 in the third horizon. In the top horizon the sum of mobile phosphorus $\left(\mathrm{P}_{2} \mathrm{O}_{5}\right)$ made $42.50 \mathrm{mg} / \mathrm{kg}$, in the second -32.50 , and in the third $26.67 \mathrm{mg} / \mathrm{kg}$. Exchange potassium $\left(\mathrm{K}_{2} \mathrm{O}\right)$ decreases from $233.77 \mathrm{mg} / \mathrm{kg}$ in the first horizon sharply to 155.44 in the second. In the third horizon decrease in the sum insignificantly - to 140.98. $\mathrm{pH}$ sum in the top horizon made 7.7 with insignificant increase with depth -7.85 in the second and 8.05 in the third horizons. Indicators of ES salinity fluctuate between $0.50-0.47-0.45$.

Reduction of power of a profile of the soil as a result of the amplified pasturage of cattle is clearly traced. 
Peaty and cespitose and peaty soils high-humus, and the humus horizon is quite powerful. It is explained by abundance of the vegetable remains, impurity of mushrooms and lichens, and also intensity of process of formation of a humus. As for low-power peaty and cespitose soils of the top part of the Alpine zone, where slopes much more coolly though in them more root remains, the maintenance of a humus doesn't exceed 10$15 \%$. Possibly, hymification process in them proceeds poorly and a quantity of a humus is washed away.

As showed calculations, in typical peaty soils where the quantity of a humus sometimes reaches $35-40 \%$, in top $(0-20 \mathrm{sm})$ a layer the stock of a humus reaches $600 \mathrm{t} / \mathrm{hectare}$, and nitrogen - about $30 \mathrm{t} / \mathrm{hectare}$. In a layer of $0-20 \mathrm{sm}$ the average powerful of sites the stock of a humus is equal in cespitose and peaty and peaty and cespitose mountain meadow soils of 350-370 t/hectare, low-power - 230-240 t/hectare, nitrogen - respectively $18-20$ and $7-10 \mathrm{t} /$ hectare. Certainly, these indicators of a stock of a humus are quite high, but it is necessary to consider that in peaty soils when determining a humus it is very difficult to select the semi-gone wrong or crushed vegetable remains, it and overestimates results of definition.
Results of the analysis of the absorbed bases and acidity according to $G$. A. Aliyev show that peaty soils of a subalpine zone and the lower part of the Alpine zone are most saturated with the bases. From the sum of $80-90 \%$ it is the share of calcium, the hydrogen ion almost is absent. The top horizons of cespitose and peaty soils of a subalpine zone (northern slope) are also well saturated the bases (40-50 mg-ekv), with depth their contents gradually decreases. Cespitose and peaty soils of the top part of the Alpine zone are less saturated.

In the same order changes in these soils and an indicator $\mathrm{pH}$. In saturated soils reaction of water suspension neutral or subacidic, in the top part of highlands - sour.

The mechanical structure of cespitose and peaty soils, is generally connected with soil forming breeds of the district, processes of aeration of radical breeds. In the field of Greater Caucasus the main types of soils are formed on clay slates, limestones and sandstones of the Jurassic age. Therefore they as a whole have to be clay and loamy.

Analyses of granulometric structure show (Table 1) that peaty and cespitose soils of a northern

Table 1. Mechanical structure of peaty and cespitose soils (with $\mathrm{HCl}$ processing)

\begin{tabular}{|c|c|c|c|c|c|c|c|}
\hline \multirow{2}{*}{ No. } & \multirow{2}{*}{$\begin{array}{l}\text { The depth, } \\
\mathrm{cm}\end{array}$} & \multirow{2}{*}{$\begin{array}{c}\text { Loss at } \\
\text { piercing, \% }\end{array}$} & \multicolumn{5}{|c|}{ Fractions (mm) (in \%) } \\
\hline & & & $1-0.25$ & $0.25-0.05$ & $0.05-0.01$ & $0.01-0.005$ & $0.005-0.001$ \\
\hline \multicolumn{8}{|c|}{ According to G. A. Aliyev } \\
\hline 344 & $\begin{array}{c}0-3 \\
5-12 \\
18-30 \\
35-42 \\
45-55\end{array}$ & $\begin{array}{l}- \\
- \\
- \\
-\end{array}$ & $\begin{array}{c}3.8 \\
6.6 \\
9.5 \\
41.9 \\
11.6\end{array}$ & $\begin{array}{l}11.8 \\
29.4 \\
13.5 \\
14.6 \\
22.0\end{array}$ & $\begin{array}{l}37.6 \\
25.2 \\
27.8 \\
12.3 \\
20.4\end{array}$ & \begin{tabular}{c|}
6.8 \\
9.8 \\
13.6 \\
6.4 \\
14.0
\end{tabular} & $\begin{array}{l}12.4 \\
12.8 \\
21.4 \\
13.6 \\
20.4\end{array}$ \\
\hline 1406 & $\begin{array}{c}0-15 \\
15-52\end{array}$ & $\begin{array}{l}6.61 \\
0.46\end{array}$ & $\begin{array}{l}0.25 \\
0.46\end{array}$ & $\begin{array}{l}34.63 \\
24.18\end{array}$ & $\begin{array}{l}44.88 \\
23.24\end{array}$ & $\begin{array}{c}6.40 \\
11.60\end{array}$ & $\begin{array}{c}5.12 \\
23.76\end{array}$ \\
\hline 1308 & $\begin{array}{c}0.24 \\
24-38\end{array}$ & $\begin{array}{l}1.23 \\
6.79\end{array}$ & $\begin{array}{c}10.79 \\
9.25\end{array}$ & $\begin{array}{l}47.93 \\
20.43\end{array}$ & $\begin{array}{l}22.56 \\
27.68\end{array}$ & $\begin{array}{c}4.48 \\
13.12\end{array}$ & $\begin{array}{c}6.32 \\
19.44\end{array}$ \\
\hline 665 & $\begin{array}{c}0-6 \\
10-15 \\
25-30 \\
50-55 \\
95-100\end{array}$ & $\begin{array}{l}- \\
- \\
- \\
- \\
-\end{array}$ & \begin{tabular}{|c|}
9.8 \\
6.4 \\
7.8 \\
19.4 \\
33.7
\end{tabular} & $\begin{array}{c}38.5 \\
9.6 \\
15.1 \\
3.2 \\
31.5\end{array}$ & $\begin{array}{c}9.2 \\
15.4 \\
9.9 \\
12.0 \\
4.8\end{array}$ & $\begin{array}{c}6.6 \\
13.0 \\
13.6 \\
11.2 \\
5.0\end{array}$ & $\begin{array}{l}11.5 \\
17.9 \\
22.2 \\
28.8 \\
10.8\end{array}$ \\
\hline \multicolumn{8}{|c|}{ According to I. I. Mardanov } \\
\hline 21. & $\begin{array}{c}\text { A1 } 0-10 \\
\text { A2 } 10-18 \\
\text { BC18-30 }\end{array}$ & $\begin{array}{l}- \\
- \\
-\end{array}$ & $\begin{array}{l}2.09 \\
4.85 \\
1.16\end{array}$ & $\begin{array}{l}22.38 \\
18.46 \\
18.19\end{array}$ & $\begin{array}{l}34.08 \\
43.14 \\
44.07\end{array}$ & $\begin{array}{l}7.57 \\
3.74 \\
5.13\end{array}$ & $\begin{array}{l}21.88 \\
14.76 \\
12.35\end{array}$ \\
\hline 20. & $\begin{array}{l}\mathrm{A}_{1} 0-5 \\
\mathrm{~A}_{2} 5-15 \\
\mathrm{~B} 15-25 \\
\text { C } 25-30\end{array}$ & $\begin{array}{l}- \\
- \\
- \\
-\end{array}$ & $\begin{array}{l}2.51 \\
3.25 \\
1.76 \\
1.68\end{array}$ & $\begin{array}{l}21.14 \\
19.81 \\
19.23 \\
18.31\end{array}$ & $\begin{array}{l}33.26 \\
41.10 \\
40.26 \\
36.75\end{array}$ & $\begin{array}{c}6.74 \\
4.33 \\
5.52 \\
11.85\end{array}$ & $\begin{array}{l}21.57 \\
16.27 \\
13.32 \\
12.08\end{array}$ \\
\hline
\end{tabular}


slope the sandy loam. In a profile of this section the clay maked of a middle part is clearly observed. As a whole, it is characterized by shaliness.

Important stage in an assessment of a current state of soil and ecological conditions of the basin of the river Gudialchay proceeding on the Northeast slope of Greater Caucasus is data processing physicalchemical analyses of the soil samples taken on characteristic sites of this territory, to some extent subject influence natural and anthropogenous factors.

As the extensive mountain and meadow massif which is rather characteristic for a subalpine subbelt, we chose a neighborhood of the settlement Hynalyg with distribution mountain meadow peaty soils. It is located on the southern spurs of system of Lateral Range, with large the poorly inclined sites. The top part of subalpine meadows in this site characterized a section No. 21. It is put in kilometer to the northeast from the village Hynalyg, near the plateau the figurative movement littered with weeds, to the southeast from top of Gyzylgaya at the height of 2500 meters above sea level. Soil mountain meadow peaty, the messy cespitose, moderately eroded. The bias of a slope makes $45^{\circ}$.

Other site on which the section No. 20 is put, is located to the northwest from the settlement Hynalyg at the height of 2200 meters above sea-level, on a slope with a bias $45^{\circ}$ on the left river bank Roser, the left inflow of the river Gudialchay. The weed vegetation in the conditions of an intensive soil erosion is developed. This site is actively used as pasture near the village by the settlement population. Along the bed of the river Roser the alluvial and proluvial river-bed deposits testifying to its hydraulic power are developed. Soil moderately eroded.

Data of analyses of soil samples revealed deterioration of indicators of quantity of nutritious elements in this type of soils including, humus and nitrogen. In a section No. 21 the horizon of $\mathrm{A}_{1} 0-10 \mathrm{sm}$ is characterized by quantity of a humus in $9.21 \%$, with reduction in the bottom layers to 7.03 and $5.48 \%$. Such situation eloquently testifies to degradation of all mountain meadow landscape owing to proceeding application of distant-pasture cattle breeding on summer pastures. Quite often these pastures are a place of origin of fatsias of aggressive character - the ravines deprived of a cespitose cover of bared sites, a being shown in the form of centers plane and linear erosion soil cover.

All considered results of analyses convince that mountain meadow peaty soils of east part of Greater Caucasus are formed in rather dry and warm ecological conditions, than differ from similar soils of other regions.

Most part of sites inconvenient for farming, both the Southern slope, and the Northeast slope of Greater Caucasus Range, including, in a river basin of Gudialchay, are conditionally inconvenient, i.e. with application of the relevant meliorative activities they can be returned to a pasturable turn.

Materials of aeration of these slopes actively collect on their feet, forming the clarified granular strip on the aerial photographs, passing into the scatterings which are breaking off slopes of mountain meadows of a river basin of Gudialchay.

Without watching rather smaller absolute height in comparison with such tops as Bazardyuzyu, Tufandag and Shakhdag, on Hynalyge, being characterized existence of accurately expressed glacial forms of a relief, snow sites with exits of rocky and detrital breeds occupy extended strips. Most likely, over continuous snow patch the big steepness of this part of the Northeast slope of Greater Caucasus and, in particular, Gaytar-Godza spine in comparison with Lateral Range is the reason of prevalence of such sites. Such steepness causes, apparently, shift of snow masses down on slopes and a drain of thawed snow at a pro-thawing of snow patch during the warmest periods.

There is a probability what exactly thawed snow of these massifs during intensive thawing serve as the reason of carrying out of a the messy detrital material of taluses, widespread on the southern slopes to the bed of the river Gudialchay, proceeding through some landscape zones, increasing torrential danger in this fragment of a mountain belt of the North-east slope of Greater Caucasus. Though this territory not differs existence of a large number of settlements and danger of influence of the exo dynamical processes on dwellings of people is rather limited, but the situation can cardinally will change with continuation by active involvement of this territory located in close proximity to the settlement Hynalyg, having ethnographic value in tourist activity in the conditions of a park mode.

\section{Offered actions}

Except reserved territories, subalpine and Alpine meadows of Greater Caucasus are a zone of active land use as summer pastures which plays large role in providing the population of Azerbaijan, Georgia and the South of Russia meat and dairy products. Therefore the problem of prevention of an erosion of soils is for this region and, as a whole, all South Caucasus important 
both with ecological, and from the economic point of view. As an alternative for achievement of ecological balance tourism development in highlands with a similar environment (Bayzhanova 2007) is quite often offered to traditional system of managing.

As very effective measure from both points of view, having positive experience of application, implementation of a reserved mode on the special dangerous in the erosive relation basins of the rivers which are flowing down from the southern slope of Greater Caucasus Range can be offered. So, creation of several national parks in this territory will serve as a turning point on a way of achievement of the nature protection purposes.

It should be noted that creation of one national park or the reserve means carrying out the anti erosion - the forest meliorative, agro technical, organizational actions, carrying out roads, tracks, the organization of work of various park services and for service of tourists. These works demand attraction of a local manpower that in turn, is important help in a solution of the problem of employment of inhabitants of mountain settlements.

Northeast slope of Greater Caucasus and, including, its mountain part presented by mountain-meadow and rocky-nival landscape zones along with development of adverse natural and destructive processes, are attractive to carrying out tourist routes because of existence both natural, and historical monuments. Such, generally pedestrian passes can give the chance to tourists to survey a variety of an environment and a consequence of the elements which are an integral part of these natural complexes (Prudnikova 2006).

Works on development of the tourist industry in this area are complicated by the big steepness of slopes and high seismicity that, can lead to change of construction plans towards strengthening of seismic stability, increase in expenses. The landslide phenomena were more than once the cause of destructions of settlements and death of people and therefore works on creation of recreation areas in this territory demand very attentive relation to a geological structure and geomorphological conditions.

Actions for expansion of travel business in highlands need an assessment of natural factors and territories concerning possibility of conducting recreational activity, gradation of certain massifs on possible risks at implementation of the planned functions that is a subject of researches of scientific other highlands (Zaporozhchenko 2005; Kononova, Mal'neva 2003).
While there is no system of the notification of tourists in case of probability of loss of storm rains, a hail, a descent of landslides, rockfalls, etc. This work can prevent many troubles of stay of tourists in the territory of highlands, introduce amendments on a choice of tourist routes and determination of their terms that is actual and for other regions of the world. Besides, there is a danger deterioration of a soil biota owing to uncontrollable development of ecotourism, such as, in some regions of Kazakhstan (Vudvord 2007). Active involvement of this territory to the phere of implementation of travel business does necessary carrying out the important security measures which systemacity can sometimes prevent tragic consequences for tourists of the negligent relation to the elements. Existence of such dangers is noted in works of many researchers of adjacent highlands (Tavasiev, Galushkin 2007).

Carrying out these measures has to will be preceded by complex field and cameral researches for a geodynamic assessment of a surrounding landscape. Results of these researches are able to afford to allocate different categories of a massif on degree of susceptibility to natural and destructive processes and their activity.

For easing or prevention of the degradation processes and as their consequence - mud streams needs to be expanded in every possible way implementation of the phyto meliorative actions directed on restoration of a continuous vegetable cover of mountain meadows.

Regulation of a superficial drain on slopes is able to provide a full-fledged water mode in the territory of all river pool. Anti erosion and anti torrential actions (forest meliorative, hydro technical, grass crops), carried out on the same site have to supplement integrally each other at observance of their sequence.

For a mountain meadow zone a radical measure of fight against an erosion of soils is the ban on its use as a pasture or regulation of a pasture of cattle in the basin of the mud-flow carried river with use of shelter system of pasturage (Stepanov, Yafyazova 20011). At use of system pasture rotation integrity of a cespitose layer and erosion process isn't broken. This system means division of a pasture into 5-6 parts and these sites are stretched along slope width. On the pitted sites the cattle is started only in 25-30 days that leads to restoration of vegetation and sod, securities of a cespitose layer from a superficial drain and an erosion.

Numerous researches show that on the Northeast slope of Greater Caucasus, including, in a river basin of Gudialchay within a mountain and forest zone there is enough of the treeless areas, glades with a close 
grassy vegetable cover that materials of a interpretation of aerial photographs which can be quite pitted by cattle confirm. Their existence allows on such sites if necessary temporarily to transfer cattle pasturage to a forest zone.

The important place in system of anti erosion actions is taken by hydro technical actions. Main them I aim, fixing of river coast by landings steady against washout and washout by shrubby plants is. Creation of stone shaft along coast, channels parallel to beds of the rivers, capable to protect slopes from the temporary water streams resulting heavy rains and intensive snowmelt is possible. These shaft have to capture a river valley on all its extent as their fragmentariness doesn't ensure safety of all settlements located along its course, including, in a mountain meadow zone. As shows the experiment, the constructed dams collapse over time under the influence of showers and the water streams which were formed thus and therefore opening of cracks on these dams through each $20-30 \mathrm{~cm}$ is desirable.

On the poorly inclined slopes of ravines there is a possibility of implementation a forest plantation in the lower part of the subalpine strip, bushes thus having on these slopes and trees have to be kept. On cool slopes forest plantations are complicated and therefore, at first it is required to plant, across slopes shrubby plants $30-40 \mathrm{~cm}$ high which are able to detain a washed-away fine earth and to create small terraces. Landings of a willow, white acacia and other fast-growing shrubby and wood plants can be thus recommended.

In this regard reduction of biases of stream of the rivers, promoting bigger accumulation of the detrital material which is taken out by a mud stream can be considered as the important direction.

As a whole, because of the big steepness and instability of a friable material of taluses and scatterings, a descent of landslides, crops of herbs on such slopes happen are complicated and demand attraction of considerable financial means. Besides, young herbs in view of a poor development of elevated and, especially, underground part poorly protect surfaces of slopes, in insignificant degree transfer a superficial drain to the intra soil. In such cases low Pletnev' devices of the dams put across slopes can be applied to detention of a drain. Along these dams shrubby plants, with branching root system can be put fast-growing in the conditions of a frigid climate. For detention of an talus material it is possible to recommend creation of low stone walls with use of a local material. Height of these stone walls increases, to $0.4-0.6 \mathrm{~m}$ and above, and the distance between them decreases depending on a bias of a slope and a condition of a surface of a talus, making from 3rd to 7 meters. For their protection it would be expedient to allocate these territories to special protected territories.

At crops of herbs on summer pastures, the preference has to be allocated for grassy plants, fast-growing from roots and having the branched root system which is well fixing the soil. Naturally, during landings it is necessary to forbid cattle pasturage, and after restoration of a soil and vegetable cover to regulate a pasture, to observe norms and the pasturable periods.

For fixing of taluses landings of a cow-parsnip of Sosnovsky can be offered. This plant isn't exacting to a fertile soil and being able grow on stony sites, taluses and scatterings. Landing of dams from this plant within several years in a row it is possible to fix big sites of slopes. It is possible to assume that the fast effect from application of this action can be reached on the Northeast slope of Greater Caucasus, including, in the river Gudialchay valley, having rather smaller energy of a relief and smaller intensity of manifestation of the morpho climatic factors, especially, the showers influencing movement of a messy detrital material. Sosnovsky's cow-parsnip is a good fodder plant and therefore can be used for development of fodder economy.

\section{Conclusions}

Soil and ecological conditions of mountain part of a river basin of Gudialchay differ influence of a difficult complex of the natural and anthropogenous factors which have created a theoretical basis of traditional system of managing. Except the severe climate causing development of pasturable cattle breeding with refusal of once cultivated mountain agriculture, in development of the soil cover play factors of a relief and the litological structure of breeds leading to development of an erosion and karstic process large role. Studying of these factors, assessment of an ecological situation and development of nature protection actions for this territory and in adjacent territories of the Northern slope of Greater Caucasus always is in the center of attention of many geographers, soil scientists and representatives of other scientific disciplines (Balamirzoev et al. 2008; Grishina et al. 1993; Ivanov, Molchanov 2003; Nosenko et al. 2006; Tavasiev, Galushkin 2007; Tsogoev 2007). In this regard there is a need of finding of balance between nature protection and economic activity in the light of active development of travel business taking into account identification of 
opportunities of melioration and recultivation of a soil cover of mountain meadows.

\section{References}

Aliev, G. A. 1978. Pochvy Bol'shogo Kavkaza (v predelakh Azerbaydzhanskoy SSR). Chast I. Baku: Elm. $157 \mathrm{s.}$

Alizade, E. K.; Tarikhazer, S. A. 2010. Ekzomorfodinamika rel'yefa gor $i$ ee otsenka (na primere severo-vostochnogo sklona Bol'shogo Kavkaza). Baku. 236 s.

Bayzhanova, Sh. B. 2007. Ekologicheskiy turizm kak al'ternativa khozyaystvennoy deyatel'nosti v bufernykh zonakh osobo okhranyaemykh prirodnykh territoriy, Vestnik Nasionalnoy Akademii Nauk Respubliki Kazaxstan 5: 71-74.

Balamirzoev, M. A.; Mirzoev, E. M.-R.; Adzhiev, A. M.; Mufaradzhev, K. G. 2008. Pochvy Dagestana. Ekologicheskie aspekty ikh ratsional'nogo ispol'zovaniya. Makhachkala: GU "Dagestanskoe. knizhnoe izdatelstvo."336 s.

Vudvord, D. B. 2007. Vliyanie ekoturistkoy deyatel'nosti deyatel'nosti na mikrobiologicheskiy sostav pochv, in $\mathrm{Ma}$ terialy II Mezhdunarodnoy nauchno-prak. konferentsii "Aktual'nye problemy ekologii i prirodopol'zovaniya $v \mathrm{Ka}$ zakhstane i sopredel'nykh territoriyakh", 23-24 oktyabrya 2007, Pavlodarskiy Gosudarstvennyy Universitet, Pavlodar, Kazakhstan, 1: 42-44.

Grishina, L. A.; Onipchenko, V. G.; Makarov, M. I.; Vanyasin, V. A. 1993. Izmenenie svoystv gorno-lugovykh al'piyskikh pochv Severo-Zapadnogo Kavkaza v razlichnykh ekologicheskikh usloviyakh, Pochvovedenie 4: 5-11.

Ivanov, A. L.; Molchanov, E. N. 2003. Okhrana i ratsional'noe ispol'zovanie pochvennogo pokrova gor Severnogo Kavkaza, Vestnik Rossiyskoy akademii selskoxozyaystvennix nauk 5: 7-10.

Zaporozhchenko, E. V. 2005. Seli severnogo sklona Tsentral'nogo Kavkaza: otsenka opasnosti i kharakteristik, printsipy inzhenernoy zashchity, in Makkaveevskie chteniya - 2004. R. S. M.: Izd-vo Moskovskoqo Gosudarstvennoqo Universiteta, 26-35.

Kononova, N. K.; Mal'neva, I. V. 2003. Vozniknovenie chrezvychaynykh situatsiy, obuslovlennykh razvitiem opasnykh geologicheskikh protsessov na Severnom Kavkaze i ikh prognoz na blizhayshee desyatiletie, in Problemy prognozirovaniya chrezvychaynykh situatsiy: Doklady. i vystupleniya na II nauchno-prakticheskoy konferensii., 23 oktiabria 2002, Moskva, Russia, Tsentr "Antistikhiya" MChS RF, 160-166.

Kyul', E. V.; Marchenko, P. E. 2012. Voprosy ustoychivogo razvitiya gornykh territoriy s uchetom vliyaniya opasnykh prirodnykh protsessov (na primere Kabardino-Balkarskoy Respubliki), Izvestiya Kabardino-Balkarskogo Nauchnogo Tsentra Rossiyskoy Akademii Nauk. - Nal'chik 4: 89-97.

Mardanov, I. I.; Abdurakhmanova, I. G. 2007. Ekzogennoe rel'yefoobrazovanie v vysokogornoy chasti Severo-Vostochnogo sklona Bol'shogo Kavkaza, Izvestiya Azerbaydjanskoqo. Natsionalnoqo Aerokosmicheskoqo. Agenstva, fizikotekhnicheskie problemy distantsionnogo zondirovaniya Zemli 10(1-2): 61-65.

Nosenko, G. A.; Rototaeva, O. V.; Nosenko, O. A. 2005. Vozmozhnosti monitoringa iz kosmosa opasnykh glyatsial'nykh protsessov $\mathrm{v}$ trudnodostupnykh gornykh rayonakh (na primere Karmadonskoy katastrofy 2002 g.), Issledovanie zemli iz kosmosa 1: 75-81.

Prudnikova, N. G. 2006. Podkhody k otsenke territorii dlya rekreatsionnoy deyatel'nosti, in N. G. Prudnikova. Geograf. i turizm: Sbornik nauchnix trudov Vypusk. 3. Perm': Izdatelstvo Permskogo gosuniversiteta, 187-203.

Stepanov, B. S.; Yafyazova, R. K. 2011. Zashchita ot seley. Problemy otsenki selevoy aktivnosti, Gidrometeorologiya $i$ ekologiya, Ezhekvartal'nyy nauchno-tekhnicheskiy zhurnal 4: 39-52.

Tavasiev, R. A.; Galushkin, I. V. 2007. Opasnye prirodnye protsessy v Tseyskom ushchel'ye i ikh vliyanie na rekreatsionnyy kompleks, Vestnik VNTs 7(2): 23-29.

Tsogoev, F. B. 2007. Ekologicheskaya bezopasnost' gornykh territoriy Respubliki Severnaya Osetiya-Alaniya: Sotsiokul'turnyy analiz. Vladikavkaz: SOGU. 236 s.

Ilham Ildirim oglu MARDANOV was born in $25^{\text {th }}$ July of 1965 in Baku. He graduated from Azerbaijan State Pedagogical University in 1987 with a degree in geography and biology. In 1990 he graduated from the graduate school of the Institute of Erosion and Irrigation of the National Academy of Sciences of Azerbaijan. In 1996 he defended a dissertation of the candidate of agricultural sciences. Since 2009 he worked as an assistant of professor of the Branch of Physical Geography of Sumgait State University. He is working on dissertation of doctor of geographical sciences now. 